\title{
Bricolage: A State of Entrepreneurial Excellence
}

\author{
S V Chinyoka ${ }^{1}$ \\ ${ }^{1}$ Department of Management, University of Botswana, Gaborone, Botswana \\ Correspondence: Associate Prof S V Chinyoka, Department of Management, University of Botswana, P. O. Box \\ 2633, Gaborone, Botswana.
}

Received: October 26, 2017

Accepted: November 15, 2017 Online Published: November 20, 2017

doi:10.20849/abr.v2i3.223

URL: https://doi.org/10.20849/abr.v2i3.223

\begin{abstract}
Purpose

The purpose of this conceptual paper is to discuss the concept of bricolage. It defines the term bricolage and its personified form 'bricoleur'. The paper attempts to identify some measures of bricolage that can assist to relate that concept to either growth of enterprises or their performance. The paper also relates bricoleurs to entrepreneurs. Lastly, the paper asks whether bricoleurs are born or made.
\end{abstract}

\section{Design/Methodology/Approach}

This is an exploratory paper on a new concept, which should be pursued in more detail in subsequent research. Sources of information are mainly journal articles identified by way of Google scholar. Conclusions point to a promising concept with potential to generate a number of articles on Botswana and surrounding countries.

\section{Findings}

Conceptually defining bricolage as separate from entrepreneurship is feasible, however, discussing related issues, like metrics, becomes fussy and difficult.

\section{Practical Implications}

Taking an extreme view that entrepreneurs, as currently defined, are failing could justify the concept of bricolage. However, common sense might lead one to conclude that, perhaps those failing are not really entrepreneurs. Bricolage can be seen, then as a trait of entrepreneurship.

\section{Originality/Value}

The concept of bricolage is alien to African discourse. When presenting this paper at an African Conference in July 2017, the listeners were alarmed at the attempt to distinguish bricolage from entrepreneurship. Yet there is a wide-ranging debate in the world. These listeners, though experienced researchers in entrepreneurship, dismissed the concept in ignorance. Further research into the concept is justified.

Keywords: bricolage, bricoleur, entrepreneur, intrapreneurial bricolage, performance measures

\section{Introduction}

The objective of this conceptual paper is to expose and demonstrate how bricoleurs manage to attain a state of entrepreneurial excellence. In most African countries, there is a dearth of entrepreneurship. There is also a serious shortage of resources, hence for any African to succeed in business, serious maneuvering would have been undertaken. One is not talking of 'tender-preneuring' or indeed the 'know-who' processes of corruption, which are endemic on the continent. The study is based on the assumption that we are dealing with genuine entrepreneurs.

The paper will define the terms 'bricolage' and 'bricoleur' and provide their historical context since this is a relatively new topic. The paper will also look at bricolage measures and associated variables. This will later assist researchers in the area to meaningfully conduct field research to prove bricolage's mantle. A conceptual comparison of bricoleurs with other entrepreneurs would justify the topic of the present paper. Last but not least, the study will ask the classical question whether bricoleurs are born or can be trained.

\section{Bricolage}

The concept of bricolage, which is quickly developing into a theory, was introduced by the French 
anthropologist Claude Levi-Strauss in 1966 (Halme, Linderman \& Linna, 2012). It derives from the French word bricoler which means to fiddle or tinker. The concept is now used in various fields like political science, anthropology, philosophy of science, etc. Within entrepreneurship, 'bricolage' has proved useful for understanding how actors create entrepreneurial ventures and generate new technologies (Garu and Karnoe, 2003; Baker and Nelson, 2005; Baker, 2007; Di Domenico, Haugh and Tracey, 2010; Duymedjian and Ruling, 2010). It is a process through which people use and combine various resources they have 'at hand' as a means of finding workable approaches to problems and opportunities (Baker, 2007). 'Bricoleurs' are people who practice bricolage, and they start with resources at hand, and work their way towards solutions. Resources 'at hand' are personal knowledge and capabilities, initial investment, and personal networks (Mahajan, 2013). Bricolage is seen as a response to resource scarcity (Halme, et al., 2012).

Bricolage may also involve the exploitation and manipulation of 'symbolic' resources, as in its original depiction, Levi-Strauss uses the concept in a semiotic sense (symbolic), expressing how actors "build ideological castles out of debris of what was once a social discourse" (Levi-Strauss, 1967, p. 21). Common actions described in bricolage include 'bias for action', 'making do', and 'relaxing the rules of what resources could or could be used for', to create innovative solutions (Baker, 2007). Bricoleurs show a disdain for the rules, often challenging the biases of existing patterns of meaning, ignoring precedents and values assigned to resources at hand (Baker and Nelson, 2005). Bricoleurs often gather and keep resources, "just in case" (Levi-Strauss, 1966).

Bricolage occurs also within large organizations, although we normally associate large organizations with resource availability. In this context, Halme, Lindeman and Linna (2012) defined intrapreneurial bricolage as entrepreneurial activity within a large organization characterized by the creative bundling of scarce resources. Intrapreneurship, itself, is a process where individuals within organizations pursue new opportunities and depart from the customary in a spirit of entrepreneurship (Antoncic, 2001, 2003; Schumpeter, 1934).

In pursuing their initiatives, intrapreneurs go beyond conventional limitations and boundaries and take on additional risks that other employees would not be prepared to consider (Carrier, 1994). It is necessary to have organizational support systems that provide resources, autonomy, and emotional support for intrapreneurs (Russell, 1999). Hence, while the ordinary intrapreneur can receive resources, autonomy, and emotional support from organizational support systems, the intrapreneurial bricoleur pushes on without any of these. These bricoleurs, like innovators, refuse to be limited by organizational and other constraints, putting-in considerable efforts to circumvent them: they resort to a number of out-of-ordinary means at hand to push the innovations forward (Halme, et al, op.cit.).

Bricoleurs, whether intrapreneurial or entrepreneurial must possess intrinsic motivation, for without it, they cannot succeed, hence can neither be termed entrepreneurs nor intrapreneurs, let alone bricoleurs. They are not motivated by potential profits since they act like social entrepreneurs (Brenneke and Spitzeck, 2010).

Bricolage activities include mobilizing resources both internally (if intrapreneurial bricoleurs) and externally. Resources are any means at hand that could help the bricoleur - technologies, free time, professional and private networks and roles, tactics for mobilizing resources (like persuasion and translation); it is said that resourcefulness is a mindset for bricolage (Halme, et al., op.cit.). This mindset is manifested in a willingness to tackle extremely challenging problems.

\subsection{Performance Measures}

Bricolage can only become a useful concept if it can make a difference in firm performance. As Levi-Strauss himself stressed, bricolage can sometimes generate "brilliant unforeseen results" (Levi-Strauss, 1966, pg. 17). These results allow early stage firms to survive and persevere in the face of problems.

Performance measures typically used in entrepreneurship include assessments of firm emergence. This might include the process of firms completing activities to enable them to become operational (Davidsson \& Gordon, 2012). Obviously, firms that become operational are preferred to those persisting or terminating, and those persisting are preferred to those terminating. In these assessments, firms controlled by bricoleurs would perform exceedingly better in these areas than those controlled by non-bricoleurs.

More common measures in entrepreneurship are firm sales (Carter et al., 1996), or growth (Delmar et al., 2013). So far, very few bricolage studies have attempted to explicitly evaluate these performance measures. Senyard et al. (2015) present three important and interrelated mechanisms that better explain the positive relationship between bricolage and firm performance. These are speed of development, co-creation and innovativeness.

Speed of development is the ability to move quickly from ideas to actual products or solutions (Kessler \& BIerly, 2002). It is an important process that influences firm performance. A bricoleur or bricolage activities can 
significantly speed development as resource availability is crucial. Bricoleurs through a bias for action, create "momentum" (Garud \& Karnoe, 2003:277) typically making do with what is on hand. Several researchers conclude that faster development and deployment allow firms to establish a competitive edge over competitors (Chen, Reilly and Lynn, 2005), secure favourable market positions (Smith \& Reinertsen, 1991) which significantly contribute to firm performance. This stands in contrast to other typical behaviours in response to constraints - delay, downsize or give up (Baker \& Nelson, 2005). Firms led by non-bricoleurs, who engage in the more traditional resource-seeking behaviours, will find themselves engaging in the time-consuming processes of attempting to attract new stakeholders (Bhide \& Stevenson, 1999) or investments (Brush, Greene and Hart, 2001) into their firms, creating delays in the process.

Co-creation is a bricolage activity where customers are involved, including active engagement and input into design to create solutions more aligned with customer needs, thus increasing satisfaction. This collaboration also provides access to valuable relevant resources at reduced or no cost (Baker \& Nelson, 2005).

Bricoleurs are more likely to generate innovative solutions than firms not engaging in bricolage since their bias for action leads them to tinker extensively with existing resources. Baker \& Nelson (2005) conclude that bricoleurs often create unique solutions through the "development of a diverse trove which is applied through a permissive and flexible approach to design".

These three mechanisms led Senyard et al. (2015) to hypothesize that bricolage has an overall positive effect on the performance of nascent firms and it has an overall positive effect on early stage firm sales.

Baker and Nelson (2005) observe that bricolage is not a silver bullet. By this, they meant that more bricolage does not necessarily imply more positive results. What they termed "excessive" and "parallel" bricolage could lead to the limitation of growth (Baker and Nelson, 2005). Instead, they recommended what they termed "selective" bricolage.

On the subject of measuring bricolage, which would assist in the distinction between selective and excessive bricolage, Baker and Nelson alert us to the fact that bricolage is described on a multi-level basis of individuals, tasks and resources, hence when relating it to firm growth, it has to be considered at that multi-level basis. They also note that bricolage may manifest in five different environmental domains that they place under three categories: (i) inputs, consisting of physical inputs, labour and skills; (ii) customers or markets; and (iii) the institutional and regulatory environment (Ronkko, Peltonen and Arenius, 2014). If bricolage is undertaken in all five domains, the result could be what they termed "bricolage identity" or a "permissive community of practice" hindering growth by reducing the firm's ability to identify and seize opportunities in broader markets (Ronkko, et al., 2014). They state however, that if bricolage manifests in fewer domains, the resource-driven growth mechanism dominates in what they term "selective bricolage". In short, bricoleurs are likely to succeed if they practice bricolage in fewer domains than taking on more.

Bricolage may be used in any of the three domain categories. A bricoleur may target the input category, which includes physical resources, labour and skills. Such entrepreneurs tend to maintain a broad category of tools, parts and other physical resources (Ronkko, et al., 2014). These entrepreneurs, it is reported, are frequently self-taught, jacks-of-all trades, instead of formally educated and specialized engineers. Secondly, bricoleurs may target customers or markets. In this case, they would experiment and use customers in their field work as a source of labour or expertise. They would also serve anyone they could, instead of focusing on certain types of customers. They relate so well with their customers that they form a community of friends with customers. Thirdly, with respect to the institutional and regulatory environment, they create novel solutions with resources at hand, including the negative side of disregarding regulations relating to the environment and work safety (Ronkko, et al., 2014). It is not surprising that entrepreneurs would often run afoul of the law through operating without a licence, failing to pay due taxes, or even putting up structures without the proper Environmental Impact Studies required by authorities.

At the present moment, one of the existing scales is one developed by the CAUSEE Project (Senyard, Baker \& Davidsson, 2009), a scale also based on the definition of bricolage by Baker and Nelson (2005). It contains three dimensions: i) use of resources at hand; ii) making do; and iii) resource combinations applied to new problems and opportunities. The scale contains eight items which are rated on a five-point basis, from "never" to "always". The scale is designed to measure how common bricolage is within a firm without considering domains in which bricolage manifests (Ronkko, et al., 2014). This is a weakness since a firm may receive a high score when engaging in bricolage in one domain. This is why Ronkko and company are proposing measures based on domains to enhance quantitative research on the bricolage/growth relationship.

Senyard, Baker, Steffens and Davidsson (2014) tested the effect of bricolage on innovativeness for new firms 
that are resource constrained. Their measures were based on four dimensions of innovativeness of new firms: i) product innovativeness; ii) process innovativeness; iii) marketing methods innovativeness; and iv) target market selection innovativeness. They also used a four-level scale: (0) initiative; (1) substantial improvement compared with existing offerings in the industry; (2) entirely new to the industry; and (3) new to the world.

As a summary to this complex section, it should be noted that bricolage is both a qualitative phenomenon and a multi-dimensional construct. While it is desirable to find metrics that can easily relate it to growth or performance of the firm, it is conceptually difficult to easily come to such metrics. Most researchers will continue using ordinal measures derived from scales like the Likert scale.

\section{Bricoleurs and Entrepreneurs}

A sub-heading like this seems to be an attempt at splitting hairs. This is so, because from a superficial understanding of bricoleur and entrepreneur, the two are the same, except that a bricoleur, perhaps is a 'more intense' entrepreneur. An important construct in entrepreneurship is entrepreneurial passion (EP), defined as the individual's strong, positive inclination towards entrepreneurial activities (Murnieks, Mosakowski and Crodon, 2014). Among new firms, the effects of the entrepreneur's passion are manifested in firm survival. Highly passionate entrepreneurs (about their start-ups) use bricolage, an entrepreneurial approach to resource building and utilization. Stenholm and Renko (2016) suggest that entrepreneurial passion is an antecedent to bricolage, which becomes a mediator to early survival.

Baker and Nelson (2005) provide an answer to our quest for a relationship between bricoleurs and entrepreneurs as they state that entrepreneurs have essentially three options when confronting environments that present new challenges without providing new resources: (1) to seek resources from domains external to the firm; (2) to avoid new challenges by remaining inert and downsizing; or (3) to enact bricolage by making do by applying combinations of resources at hand to new problems and opportunities. Passionate entrepreneurs are unlikely to follow path number two outlined above, since this limits their entrepreneurial roles, hence detrimental to their perceived self-worth and happiness. An entrepreneur who is passionate about inventing entrepreneurial solutions, founding a firm, and developing that firm through the early resource scarcity, is more likely to engage in bricolage than someone whose feelings about entrepreneurship are lukewarm (e.g. someone forced into business ownership because of the lack of other opportunities for work) (Stenholm and Renko, 2016). In other words, passion differentiates an ordinary entrepreneur from a bricoleur, who can be defined as an extraordinary entrepreneur due to the passion. Survival of new firms that face resource challenges is only assured by bricolage activities which are embarked upon by passionate entrepreneurs. This explains the role of bricolage as a mediator variable to early survival.

\subsection{Can Bricoleurs Be Made?}

The debate on whether entrepreneurs (hence bricoleurs) are born or made has been going on for long and continues unabated. Both sides of the debate are intense and often argue their cases with a lot of 'entrepreneurial' zeal. One Tshivhase (2014) proposes that, even if a person can acquire entrepreneurial education, but lacks the natural talent to thrive; little progress will be made to invent incomparable business ideas to change the world. One, Lord Alan Sugar, a famous entrepreneur stated that it does not matter which business school you go to or what books you red, you can't go into Boots and buy a bottle of entrepreneurial juice - entrepreneurial spirit is something you are born with (Mitchell, 2014).

However, many others, particularly business developers, believe otherwise. For instance, serial entrepreneur Jonathan Richards believes that an entrepreneurial mindset is the sum of all our experiences, and it is not something we are born with (Mitchell, op.cit.). He states that "an entrepreneur is created when an idea comes together with a person who is happy to balance creativity and management; understand, live with and manage risk; evangelize the idea in the face of negativity; and stay responsive and positive".

The latter view seems more realistic. Indeed people are "born" with different aptitudes, or can we say people grow up developing different aptitudes, but this does not mean that they cannot re-learn other aptitudes. In religious language, God creates people with different talents, but gives all the capability of learning! 
The following conceptual model is developed by Stenholm and Renko (2016):

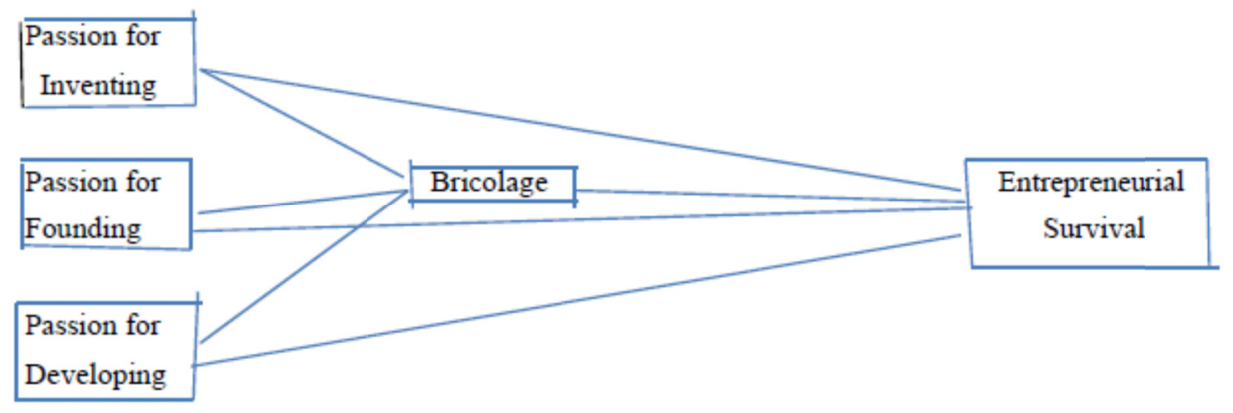

Figure 1. The Concept Model by Stenholm and Renko (2016)

The only characteristic a person can claim to have been 'born' with is 'passion'. It is a characteristic that can also be developed. A person who is generally passionate can also channel his or her passion towards different activities, for example, towards inventing, founding or developing. Such would be classified as an entrepreneur. An entrepreneur can endeavor or even be trained to be a bricoleur (perform bricolage activities) which act as mediator to early survival. In conclusion, while people are born with different aptitudes, it is up to them to develop them into particular strengths of choice. Entrepreneurs and bricoleurs are made.

\section{Discussion}

New terms and concepts continue to surface in the area of entrepreneurship. Some of these concepts are borrowed from sister disciplines, and they are found to enrich both the understanding and the analysis of original concepts in entrepreneurship. Bricolage is an example of such concepts. One would have thought that entrepreneurship, supported by scores of traits, would be the ultimate concept in this field. Nay, new concepts continue to crop up.

This paper has attempted to define the terms bricolage and bricoleur, review attempt to refine measures related to bricolage and economic growth or economic performance, relate bricoleurs to entrepreneurs, and debate the old question of whether entrepreneurs and bricoleurs are born or made.

In defining the terms 'bricolage' and 'bricoleur', literature emphasizes the ability of 'making do' with existing resources and combining resources for tackling new problems and achieving new opportunities. There are a number of dimensions where these can be tackled. These definitions give an impression that a bricoleur is a sort of 'super' entrepreneur. Where an entrepreneur may fail or face delays, a bricoleur is likely to succeed. Bricolage activities are seen as mediating entrepreneurial traits like passion to ensure success.

Literature has also shown that while the concept of bricolage is now well developed and perhaps generally understood, measures for bricolage are not well developed, hence quantitative researchers still find that there are no metrics to use. Indeed those researchers who have attempted quantitative research have ended only at ordinal measures generated by the familiar scales like the Likert scale. These are measures that can only be utilized by depending on what the bricoleurs themselves say about their activities, nothing objective yet.

In comparing entrepreneurs to bricoleurs we run the risk of comparing 'apples' to 'oranges'. In particular, one might be using the trait approach when analyzing the entrepreneur, while bricolage is an activity. There is nothing inherent in activities attached to bricolage being the bricoleur's preserve. Entrepreneurs can also perform them. This makes it difficult for analysts to compare entrepreneurs with bricoleurs.

The issue of whether entrepreneurs and bricoleurs are born or 'made' will continue to be contentious. Both sides of the argument are fully convinced that they are right, hence although one could be sympathetic to one side, the debate is unlikely to end.

\section{Conclusion}

Researchers in the area of enterprise development have embraced the concept of bricolage, a term popularized about fifty years ago. One can confidently conclude that a theory of bricolage has largely been developed and researchers like Baker and Nelson should rightly be accredited for this. There are still areas that need more intense investigation, like the need to develop bricolage measures, and finding a unifying approach to the 
analysis of entrepreneurship and bricolage. One can state that the emergence of such concepts is a wakeup call to entrepreneurship researchers to solidify their theoretical approaches. More concepts are bound to pop-up. The question remains whether there are really advances in understanding the concept of entrepreneurship or could it be merely the splitting of hairs?

\section{References}

Antoncic, B. (2001). Organizational processes in intrapreneurship: a conceptual integration. Journal of Enterprising Culture, 9(2). https://doi.org/10.1142/S0218495801000122

Antoncic, B. (2003). Risk-taking in intrapreneurship: Translating the individual level risk aversion into organizational risk-taking. Journal of Enterprising https://doi.org/10.1142/S0218495803000020

Baker T, Nelson RE (2005) Creating something from nothing: Resource construction through entrepreneurial bricolage. Admin. Sci. Quart, 50(3), 329-366. https://doi.org/10.2189/asqu.2005.50.3.329

Baker, T. (2007). Resources in play: Bricolage in the Toy Store(y). J. Bus. Venturing, 22(5), 694-711. https://doi.org/10.1016/j.jbusvent.2006.10.008

Bhide, D. E., \& Stevenson, H. (1999). Attracting Stakeholders. In W. S. a. H. Stephenson (Ed.) The Entrepreneurial Venture ( $2^{\text {nd }}$ ed.). Boston, Massachusetts; Harvard Business School Publications.

Brenneke, M. \& .Spitzeck, H. (2010). Social intrapreneurship. Working paper, Retrieved from http://www.eben.gr/.../Spitzeck\%20HEIKO\%20Intrapreneurship.pdf

Brush, C.G., Greene, P.G. \& Hart, M.M. (2001). From initial idea to unique advantage: The entrepreneurial challenge of constructing a resource base. The Academy of Management Executive, 15(1)64-78. https://doi.org/10.5465/AME.2001.4251394

Carrier, C. (1994). Intrapreneurship in large firms and SMEs: a comparative study. International Small Business Journal, 12(3). https://doi.org/10.1177/0266242694123005

Carter, N. M., Gartney, W. B., \& Reynolds, P. D. (1966). Exploring start-up event sequences. Journal of Business Venturing, 11(3), 151-166. https://doi.org/10.1016/0883-9026(95)00129-8

Chen, J., Reilly, R.R. \& Lynn, G.S. (2005). The impacts of speed-to market on new product success: The moderating effects of uncertainty. IEEE Transactions on Engineering Management, 52 (2), 199-212. https://doi.org/10.1109/TEM.2005.844926

Davidsson, P., \& Gordon, S. R. (2012). Panel studies of new venture creation: a methods-focused review and suggestions for future research. Small Business Economics, 39(4), 853-876. https://doi.org/10.1007/s11187-011-9325-8

Delmar, F., McKelvie, A., \& Wennberg, K. (2013). Untangling the relationship among growth, profitability and survival in new firms. Technovation, 33(8), 276-291. https://doi.org/10.1016/j.technovation.2013.02.003

Di Domenico M.L., Haugh H, \& Tracey P (2010). Social bricolage: Theorizing social value creation in social $\begin{array}{llll}\text { enterprises. } & \text { Entrepreneurship } & \text { Theory }\end{array}$ https://doi.org/10.1111/j.1540-6520.2010.00370.x

Duymedjian R, \& Ruling C.C. (2010). Towards a foundation of bricolage in organization and management theory. Organ. Std., 31(2), 133-151. https://doi.org/10.1177/0170840609347051

Garud R, \& Karnoe P (2003). Bricolage versus breakthrough: Distributed and embedded agency in technology entrepreneurship. Res. Policy, 32(2), 277-300. https://doi.org/10.1016/S0048-7333(02)00100-2

Halme, M., Linderman, S. \& Linna, P. (2012). Innovation for inclusive business: Intrapreneurial bricolage in multinational corporations. Journal of Management Studies, 49(4), 743-784. https://doi.org/10.1111/j.1467-6486.2012.01045.x

Kessler, E.H. \& Bierly III, P.E. (2002). Is faster really better? An empirical test of the implications of innovation speed. IEEE Transactions on Engineering Management, 49 (1), 2-12. https://doi.org/10.1109/17.985742

Levi-Strauss C (1967). The Savage Mind. (University of Chicago Press, Chicago).

Levi-Strauss, C (1966). The Savage Mind. University of Chicago Press.

Mahajan, S. (2013). Women entrepreneurship in India. Global Journal of Management and Business Studies, $3(10), 1142-1148$. 
Mitchell, L. (2014). Nature or Nurture: Are entrepreneurs born or made? Retrieved from $\mathrm{http}$ ://www.busineeszone.co.uk/nature-or-nurture-are-entrepreneurs-born-or-made [14 June, 2017].

Murnieks, C., Mosakowski, E. \& Cardon, M.S. (2014). Pathways of passion: identity centrality, passion and behavior among entrepreneurs. $J$ of Manag, 40(6), 1583-1606. https://doi.org/10.1177/0149206311433855

Ronkko, M., Peltonen, J. \& Arenius, P. (2013). Selective or parallel? Towards the domains of entrepreneurial bricolage. In: Corbett, A.C., Katz, JA (Eds.), Advances in Entrepreneurship, Firm Emergence and Growth, Vol 15: Entrepreneurial Resourcefulness: Competing with Constraints (pp. 43-61). Emerald Group Publishing Ltd..

Russell, R.D. (1999). Developing a process model of intrapreneurial systems: a cognitive mapping approach. Entrepreneurship Practice and Theory, 23, 65-84.

Schumpeter, J. (1934). The theory of economic development. In E. Okum (Ed.), Studies in economic development,.64. Cambridge MA: Harvard University.

Senyard, J., Baker, T., Steffens, P., \& Davidssson, P. (2014). Bricolage as a path to innovativeness for resource-constrained new firms. Journal of product Innovation Management. 31(2), 211-230. https://doi.org/10.1111/jpim.12091

Senyard, JM, Baker, T., \& Davidsson, P. (2009). Entrepreneurial bricolage: towards systematic empirical testing. Front. Entrep. Res, 29(5), (article 5).

Senyard, Julienne M., Davidsson, Per, \& Steffens, Paul R. (2015) Environmental dynamism as a moderator of the relationship between bricolage and firm performance. In $\left(75^{\text {th }} \mathrm{Ed}\right)$. Annual Meeting of the Academy of Management: Opening Governance, 7-11, August 2015, Vancouver, British Columbia, Canada. https://doi.org/10.5465/AMBPP.2015.14893abstract

Smith, P.G. \& Reinertsen, D. G. (1991). Developing new products in half the time. New York: Van Nostrand Reinhold.

Stenholm, P. \& Renko, M. (2016). Passionate bricoleurs and new venture survival. J. of Bus. Ventur. 31, 595-611. https://doi.org/10.1016/j.jbusvent.2016.05.004

Tshivhase, L (2014). The greatest entrepreneurs are born rather than made. LTGroupings, 9, 119-144.

\section{Copyrights}

Copyright for this article is retained by the author(s), with first publication rights granted to the journal.

This is an open-access article distributed under the terms and conditions of the Creative Commons Attribution license (http://creativecommons.org/licenses/by/4.0/). 